\title{
Cognitive interventions and performance measures: a longitudinal study in elderly women
}

\author{
Intervenções cognitivas e medidas de \\ desempenho: um estudo longitudinal \\ em idosas
}

\author{
Isabelle Patriciá Freitas Soares CHARIGLIONE ${ }^{1}$ (iD) 0000-0001-8627-3736 \\ Henrique Salmazo da SILVA² (iD) 0000-0002-3888-4214 \\ Gislane Ferreira de MELO3 ${ }^{3}$ (iD) 0000-0003-3551-5963 \\ Karla Helena Coelho Vilaça e SILVA ${ }^{2}$ (iD) 0000-0002-4937-2396 \\ Maria Liz Cunha de OLIVEIRA² (iD) 0000-0002-5945-1987
}

\begin{abstract}
Several types of cognitive interventions have been performed with elderly individuals to verify physical and quality of life benefits. The objective of this study was to verify if the cognitive gains found in two cognitive intervention programs are related to changes in the mood, quality of life and physical fitness variables (maximum oxygen consumption, lean mass, fat percentage and handgrip strength). A total of 39 elderly women from the Distrito Federal (Brazil), participating in a cognitive training group based on mnemonic strategies and a group of cognitive stimulation based on perceptual and attention exercises. Both groups showed a tendency to reduce depressive symptoms, an increase in their fat mass and a decrease in their lean mass. Taken together, these findings may contribute to identify the directionality of mnemonic interventions in Brazilian elderly individuals regarding the subjective and physical performance variables.
\end{abstract}

Keywords: Cognition; Elderly; Neuropsychology; Physical fitness; Quality of life.

\footnotetext{
${ }^{1}$ Universidade de Brasília, Instituto de Psicologia, Departamento de Psicologia Escolar e do Desenvolvimento. Campus Universitário Darcy Ribeiro, 70910-900. Brasília, DF, Brasil. Correspondence to: I.P.F.S. CHARIGLIONE. E-mail: <ichariglione@gmail.com>.

${ }^{2}$ Universidade Católica de Brasília, Escola de Saúde e Medicina, Programa de Pós-graduação em Gerontologia. Brasília, DF, Brasil.

${ }^{3}$ Universidade Católica de Brasília, Escola de Saúde e Medicina, Programa de Pós-graduação em Educação Física e Psicologia. Brasília, DF, Brasil.

Support: Fundação de Apoio e Pesquisa do Distrito Federal (Process \#0193-001-227/2016).
}

$\boldsymbol{\nabla} \boldsymbol{\nabla} \boldsymbol{v}$

How to cite this article

Chariglione, I. P. F. S., Silva, H. S., Melo, G. F., Silva, K. H. C. V., \& Oliveira, M. L. C. (2020). Cognitive interventions and performance measures: a longitudinal study in elderly women. Estudos de Psicologia (Campinas), 37, e190032. http://dx.doi.org/10.1590/1982-0275202037e190032 


\section{Resumo}

Diversos tipos de intervenções cognitivas têm sido realizados com idosos para a verificação de ganhos físicos e de qualidade de vida. O objetivo deste estudo foi verificar se ganhos cognitivos apresentados em dois programas de intervenção cognitiva estão relacionados a alterações de humor, qualidade de vida e aptidão física (consumo máximo de oxigênio, massa magra, percentual de gordura e força de preensão palmar) em idosas. Foram avaliadas 39 mulheres idosas do Distrito Federal (Brasil), divididas em dois grupos: um que realizou treino cognitivo baseado em estratégias mnemônicas; e outro, de estimulação cognitiva baseada em exercícios perceptuais e de atenção. Ambos os grupos apresentaram tendência a reduzir os sintomas depressivos e obtiveram aumento de massa gorda e diminuição de massa magra. Em conjunto, esses achados podem contribuir para identificar a direcionalidade das intervenções mnemônicas em idosos brasileiros sobre as variáveis subjetivas e de desempenho físico.

Palavras-chave: Cognição; Idoso; Neuropsicologia; Aptidão física; Qualidade de vida.

Health promotion and quality of life are targets of interest for different programs and services aimed at the elderly, with an objective of regulating and compensating for functional and cognitive losses associated with the aging process. In this context, cognitive interventions for the elderly may assist in maintaining and optimizing cognitive abilities in healthy or cognitively impaired elderly individuals (Bahar-Fuchs, Clare, \& Woods, 2013; Belleville et al., 2018; Huntley, Gould, Liu, Smith, \& Howardet, 2015; Neri et al., 2018).

National and international studies have documented that, in addition to gains in cognitive performance, cognitive interventions can yield promising results in measures of well-being and quality of life in the elderly with reduced depressive symptoms (Brum, Forlenza, Yassuda, 2009; Chariglione \& Janczura, 2013; SalmazoSilva \& Yassuda, 2009) and maintaining or increasing quality of life (Fernández-Prado, Conlon, Mayán-Santos, \& Gandoy-Crego, 2012; Irigaray, Schneider, \& Gomes, 2014; Reijnders, Van-Heugten, \& Van-Boxtel, 2013; Wolinsky et al., 2006a; Wolinsky et al., 2006b).

Quality of life can be defined as the individual's perception of their position in life according to their cultural context and in line with the value systems in the society in which they live and in relation to personal goals, expectations, standards and concerns (World Health Organization Quality of Life Group, 1998). In old age, quality of life involves a multidimensional assessment established by individual, personal and socionormative criteria on the relationship between individual and environment, and considers four dimensions, overlapping and interrelated to the functionality of the elderly, such as environmental conditions, behavioral competence, perceived quality of life and psychological well-being (Lawton, 1991).

In cognitive training programs, it was observed that the increase in quality of life was more observed in the experimental group than in the control group (Fernández-Prado et al., 2012; Irigaray et al., 2014; Cabeza et al., 2018), together with cognitive gains in episodic memory; whereas other studies indicated that the maintenance of quality of life was dependent on the type of cognitive modality trained, and that a training based on processing speed was more effective for maintaining health-related quality of life in a period between two and five years, when compared to memory training and inductive reasoning (Wolinsky et al., 2006a; Wolinsky et al., 2006b).

Explanations for these findings include an increase in the individual's social network and a higher knowledge on memory and the aging process, supporting new ways of coping and regulating cognitive changes (Irigaray et al., 2014; Viscogliosi, Desrosiers, \& Belleville, 2019). Another assumption, complementary to this, may be related to physiological changes mediated by the type of cognitive intervention, eliciting changes in cortical connectivity (Wolinsky et al., 2006a; Wolinsky et al., 2006b), changes in inflammatory markers (Pesce et al., 2017) and components associated with physical fitness, showing an interdependence between cognition and physical performance (Ross, Sprague, Phillips, O’Connor, \& Dodson, 2018). 
Physical fitness encompasses physiological dimensions such as maximal aerobic power, strength, flexibility and body composition components (Araújo \& Araújo, 2000), dimensions that decline with the aging process due to decreased cardiac capacity, loss of muscle mass, increased blood pressure and visceral body fat (Fechini \& Trompieri, 2012; Kennedy, Hardman, Macpherson, Scholey, Pipingas, 2016; Silva, Souza, \& Crepaldi-Alves, 2015).

Thus, the interaction between the objective gains, related to changes in physical fitness, and the subjective ones, related to mood and quality of life, can be better examined. Studies that have examined the impact of cognitive training on the physical function are recent, documenting gains in standing balance and gait speed (Ross et al., 2018).

Ross et al. (2018) conducted a study in the United States on the impact of three cognitive training programs on objective measures of physical functioning over five years. The elderly individuals were randomly allocated to processing speed, inductive reasoning or episodic memory groups and compared to the individuals of the non-contact control group. Although no transfer effects were observed in the analyzes related to the type of cognitive ability trained, the authors observed that participation in a larger number of training sessions was associated with the maintenance of performance in the Digit Symbol-Copy task (motor speed and visual and motor coordination) and Turn 360 (motor coordination, lower limb functioning and dynamic balance) in relation to the control group. It was also observed that the group that trained inductive reasoning presented better handgrip strength levels.

However, although these results indicate associations between cognitive interventions and motor performance measures, the exact mechanisms of training transfer are unknown. It is possible that cognitive training may directly or indirectly postpone the aging-related decline of the nervous system, which would result in the maintenance of motor function performance even after the control of functions in the initial assessment, self-efficacy, and training-driven social stimulation (Ross et al., 2018). As the authors discuss, the type of trained cognitive modality, target population, and physical and cognitive outcomes should be further investigated.

In Brazil, to date, no study has investigated the impact of cognitive interventions on the physical fitness of the elderly. This studies have focused on cross-sectional analyzes between cognitive skills and physical fitness measures (Chariglione, Salmazo-Silva, Silva, Sacramento, \& Melo, 2018a), or documenting cognitive benefits associated with trained modalities, especially episodic memory training (Chariglione, Janczura, \& Belleville, 2018b; Chariglione et al., 2018a). Associations between handgrip strength and executive functions were documented; between Maximum Oxygen Consumption $\left(\mathrm{VO}_{2}\right)$ and episodic memory levels (Chariglione et al., 2018a); and cognitive gains after participating in training programs, with performance improvements that tend to be restricted to the investigated domain.

Although previous studies have already been performed with the Stimullus (Chariglione \& Janczura, 2013) or MEMO (Gagnon \& Belleville, 2012; Belleville et al., 2018) cognitive interventions, or comparing these two modalities (Chariglione et al., 2018b; Chariglione et al., 2018a), no study have focused on potential gains in physical measurements.

In this sense, the present study is an exploratory research, whose objective was to verify if cognitive gains were related to changes in the mood, quality of life and physical fitness variables. For this, initial, preand post-intervention data from the from the research group Neurociências e Cognição - Idoso (NeuroCogIdoso, Neuroscience and Cognition Research - Elderly) were examined in a sample of elderly women from the Federal District (Brazil) attending a program of different cognitive interventions within a group of elderly individuals who were monitored for two years. 


\section{Method}

This study is characterized as quasi-experimental, cross-sectional, descriptive and exploratory in nature, and analyzed the first six months of participation of the elderly individuals in cognitive interventions divided in two moments: pre-intervention and post-intervention. As this is an exploratory study, the guiding question was to verify whether there were associations between cognitive interventions and changes in mood, quality of life and physical fitness. Thus, the MEMO group was compared to the Stimullus group, so that one group served as a control for the other one, because they relied on different cognitive interventions: The Stimullus Program is a cognitive stimulation based on the coding of visual and verbal stimuli, whereas the MEMO Program refers to a systematic training of mnemonic techniques.

\section{Participants}

The sample of the present study comes from a population of 85 elderly individuals participating in a cognitive training program of the Universidade Católica de Brasilia (UCB, Catholic University of Brasilia) offered to elderly individuals of the Federal District, Brasilia, Brazil. From the total number of participants, 58 of them were evaluated. However, in the present study, in order to homogenize the sample and compare the elderly in the physical performance measures, male participants $(n=10)$ and those with an incomplete physical assessment $(n=9)$ were excluded from the analysis, excluding 19 participants. Therefore, the analyzed sample refers to 39 elderly women with and without cognitive decline in the Mini Mental State Examination (with the cutoff points according to the educational level used by the FIBRA Network (Neri et al., 2013), with a mean age of $67.77 \pm 6.34$ years (60-87). Of these participants, 37 completed the interventions and had a frequency equal to or greater than $75 \%$ in the proposed sessions, which is the sample investigated, as shown in Figure 1.

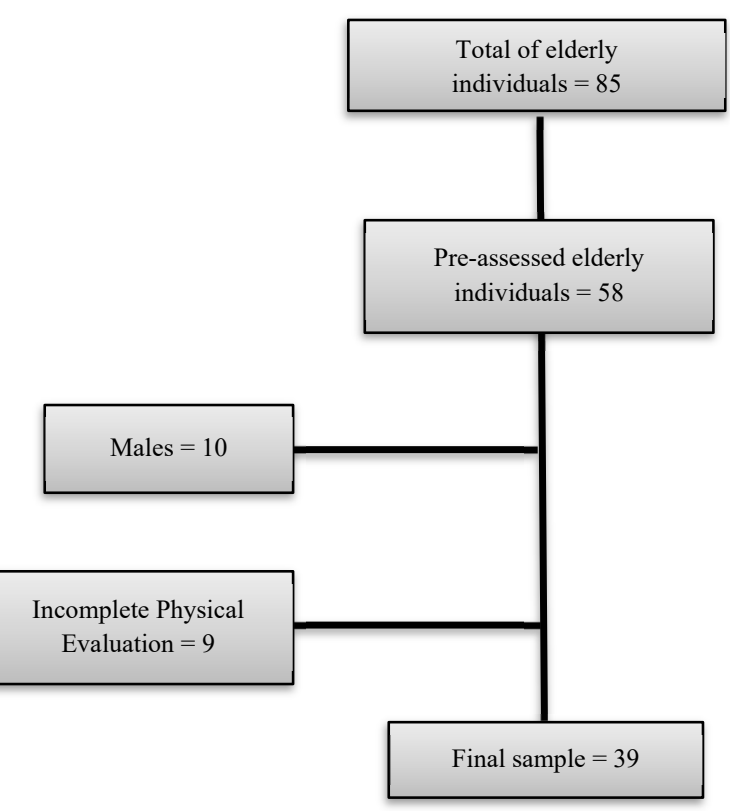

Figure 1. Flowchart of the participants. 


\section{Instruments}

The instruments applied were grouped into four categories, namely: sociodemographic, cognitive, physical and psychological. The sociodemographic assessment consisted of information on age, sex, educational level and marital status. The socioeconomic classification were analyzed according to Associação Brasileira de Empresas de Pesquisa. The cognitive assessment consisted of pencil and paper tests adapted and validated for Brazil, commonly used in elderly Brazilian individuals and with evidence of validity. The following tests were chosen: (1) Stroop Color and Word Test (Stroop): to evaluate inhibitory control and selective attention (Stroop, 1935). In this study, the Execution Time, in seconds, was chosen in the condition of inhibition of words semantically related to colors. (2) Rey Auditory-Verbal Learning Test (RAVLT): To assess learning processes, recall and recognition of episodic memory (Salgado et al., 2011). Among the RAVLT measures, the sum of the five word lists (A1 to A5) was chosen as an episodic memory measure, for it gathered an indicator of the learning curve. (3) Addenbrooke's Cognitive Examination - Revised Version (ACE-R): to evaluate five cognitive domains together and also to provide partial scores for each of them: Attention and Orientation (ACE-A), Memory (ACE-M), Fluency (ACE-F), Language (ACE-L) and Visual-Spatial Skills (ACE-V) (Carvalho \& Caramelli, 2007). (4) Mini Mental State Examination (MMSE): to assess the overall cognitive status (Brucki, Nitrini, Caramelli, Bertolucci, \& Okamoto, 2003).

The dependent variable of the study was the sum of the correct answers in the MMSE. The physical assessment was composed by the following variables, which are also used in studies with the elderly: (a) Body mass: For the measurement of body mass, a Filizola digital scale (model PL-150) was used, with a maximum capacity of $150 \mathrm{~kg}$ and an accuracy of $0.1 \mathrm{~g}$. For this measurement, the individuals were wearing as little clothing as possible, then they stood up and stayed put until the value shown on the scale display stabilized; (b) Stature: a Seca-brand fiberglass tape measure with variation in millimeters, attached to the wall, was used. For this procedure the subjects stood in upright position, with parallel heels, leaned against the wall and stood erect with their arms relaxed and the head positioned at an angle of $90^{\circ}$. In addition, their eyes should be fixed on the horizontal axis parallel to the ground (Frankfurt Line). The elderly individuals were instructed to perform deep inspiration, after these adjustments, the researchers observed the most prominent point of the head to perform the measurement; (c) Body composition: body composition measurements (percentage of fat, fat mass and lean mass) were measured through the Dual Energy X-ray Absorptiometry (DXA) method. The DXA measurements (DPX-L model, LUNAR Radiation, Madison, WI, USA) were performed by full body scanning. All examinations were analyzed by a specialized investigator using the specific software provided with the equipment for body composition analysis, LUNAR Radiation version 1.2i DPX-L; (d) Handgrip test: after getting acquainted with the equipment, the participants were told to sit down, with their shoulders in neutral position, elbows flexed at $90^{\circ}$ and wrist in neutral position. The subjects were instructed to perform the maximum isometric contraction at the examiner's verbal command. Three attempts were made by alternating the limbs, with an interval of 60 seconds. The procedure was performed respecting the criteria described by Shiratori, Rosa, Borges Júnior, Domenech, and Silva-Gevaerd (2014); and (e) Ergospirometry test: to evaluate the maximal cardiorespiratory capacity, the ergospirometry test was used, which can determine, with relative precision, the maximum $\mathrm{VO}_{2}$ with the following data: (a) presence of Respiratory Quotient (RQ) $\left(\mathrm{VCO}_{2} / \mathrm{VO}_{2}\right)>1.1$; (b) existence of an anaerobic threshold (lactate threshold); (c) Ventilation (VE) $>60 \%$ of the maximum forecast; (d) eventual presence of a $\mathrm{VO}_{2}$ plateau in the face of an increase in the effort load. This test was performed with a ramp protocol, with an initial speed of $3.0 \mathrm{~km} / \mathrm{h}$ and a final speed of 6.0 $\mathrm{km} / \mathrm{h}$, with an initial inclination of $4 \%$ and a final inclination of $14 \%$, in a maximum time of 10 minutes.

The assessment of psychological variables related to mood and quality of life were made using the following instruments: (a) Geriatric Depression Screening Scale (GDS): a 15-item instrument adapted for the Brazilian population by Almeida and Almeida (1999), based on the scale originally created by Yesavage et al. 
(1983) with 30 items, aiming to detect the absence of symptoms which could be suggestive of depression in elderly individuals. Its score ranges from 0 to 15 points, with a score of 6 points or higher being suggestive of depression; and (b) World Health Organization Quality of Life Group (WHOQOL OLD): a questionnaire consisting of 24 questions, on a Likert scale ranging from 1 to 5, divided into five domains (Autonomy; Past, Present and Future Activities; Social Participation; Death and Dying; Intimacy) (Fleck, Chachamovich, \& Trentini, 2003). In the present study, the sum of all domains was analyzed.

\section{Procedures}

The procedures followed ten stages. In the first stage, the elderly individuals were invited to participate in the study through publications in electronic media, social networks, and through actions in social groups, health services and social assistance services for the elderly in the Federal District. In the second stage, an introductory class on memory and aging was held by the researchers of the NeuroCog-Elderly Research Group, with the objective of presenting the project. In the third stage, the elderly who consented to participate in the study took part in the Cognitive Assessment by presenting the project and signing the Informed Consent Term.

In the fourth stage, the psychological assessments were performed and in the fifth stage, the physical assessment, according to the previously presented instruments. The assessments were performed on three separate days, individually and with an average length of one hour (per assessment). The cognitive assessment was conducted by graduate students in gerontology and psychology students, the psychological assessment was conducted by psychology students, and the physical assessment was performed by a graduate student in gerontology and a physical educator with the supervision of a cardiologist. All participants were instructed regarding the preparatory procedures prior to the physical assessment, such as adequate food intake and to be wearing comfortable clothing for the tests.

The assessments were completed within 30 days prior to the start of the interventions, so that there was no variable which could be an impediment to the process and group comparison. This period was monitored in the other follow-up stages of this study. Regarding the evaluators, they were blinded to the type of intervention of the participant, avoiding that the same participant would be assessed by the same evaluator at both times.

At the end of the assessments, in the sixth stage, the elderly individuals were distributed in the cognitive stimulation (Stimullus) and memory training (MEMO) groups according to the individual's age, sex and educational level, so that the participants could be compared. In this study, male participants were removed from the test for a better description and for a homogenization of the sample, because there are variables in physical fitness measures between men and women that would require analyzes stratified by sex. As the sample size of men was reduced $(n=10)$, the researchers chose not to analyze the data of elderly men in the present study. These two interventions refer to studies of refinement and adaptations of these techniques developed by Chariglione and Janczura (2013), and Gilbert, Fontaine and Belleville (2011), the latter being translated and adapted to the Portuguese language in 2014 (Chariglione et al., 2018b).

In the seventh stage the participants were recalled, at a date and time set in advance, to participate in six weekly 90-minute sessions in one of the groups. The Stimullus program sessions comprised cognitive stimulation activities, based on the discrimination of visual and auditory stimuli in the following order: (1) Visual sequence; (2) Memorization of words; (3) Memorization of sentences; (4) Categorization of words; (5) Memorization of images; and (6) Memorization of stories.

The MEMO program sessions focused on the use and training of the mnemonic strategies of categorization, the place association method, verbal association, and reading method, in the following order: (1) Memory and aging; (2) The importance of being attentive; (3) Mental image training; (4) The Loci 
method; (5) The name-face association method; and (6) The Preview, Read, Sumarize and Test method. At the end of each program, the participants were called to the eighth, ninth and tenth stages of the study, which consisted of cognitive, physical and psychological assessments with the same scales and procedures described in the stages 3,4 and 5.

\section{Data analysis}

Initially, the descriptive data of the sample were analyzed through mean, standard deviation and frequencies. For all variables, the normality was investigated through the Shapiro-Wilk test and the non-normal data were corrected according to the Tabachnick \& Fidell standard's (2012). Subsequently, the paired t-test was performed to verify the differences before and after the interventions for each investigated variable. In a second moment, each variable of interest was analyzed through an ANOVA ( $2 \times 2)$, considering the Time factor (pre and post) and the Interaction between Time and Group (Stimullus and MEMO). The Software SPSS-IBM 22.0 was used to perform the analyzes and the stipulated significance level was $p \leq 0.05$.

This study was submitted to the Research Ethics Committee of the Universidade Católica de Brasilia (Catholic University of Brasilia) and approved by the Committee Opinion No. 2.071.414, Certificado de Apresentação para Apreciação Ética (CAAE, Presentation Certificate for Ethical Appreciation) code: 67653517.4.0000.0029.

\section{Results}

As shown in Table 1, the Stimullus and MEMO groups were similar in the sociodemographic, cognitive, mood, and physical fitness variables. Table 2 presents the general effects of cognitive interventions, regardless of group (Stimullus or MEMO). Of the variables analyzed, only the performance in the RAVLT word list (Learning Curve) had a statistically significant increase in the posttest. Regarding the variables of interest, the sample of elderly women tended to reduce depressive symptoms and, at the end of the intervention, showed an increase in their fat mass and a decrease in their lean mass levels.

These findings are confirmed by the comparison of means between groups in the 2x2 ANOVA test, indicating that both groups presented these alterations, without interaction between the type of training offered (MEMO $x$ Stimullus), as shown in Table 3. There was a trend of interaction between Time $x$ Group in the WHOQOL OLD group in favor of higher scores in the MEMO Group when compared to those in the Stimullus Group ( $p=0.084$ ).

Table 1

Characterization of the sample of elderly women participating in the MEMO cognitive training groups $(n=21)$ and the Stimullus cognitive stimulation group $(n=18)$

\begin{tabular}{|c|c|c|c|c|c|c|}
\hline \multirow{2}{*}{ Variables } & \multirow{2}{*}{ Levels } & \multicolumn{2}{|c|}{ Stimullus } & \multicolumn{2}{|r|}{ MEMO } & \multirow{2}{*}{$p$-value } \\
\hline & & $n$ & $\%-M(S D)$ & $n$ & $\%-M(S D)$ & \\
\hline Age & & & $68.61(+6.04)$ & & $69.70(+7.75)$ & $p=0.684$ \\
\hline \multirow[t]{3}{*}{ Educational level } & $\begin{array}{l}\text { Did not complete } \\
\text { Elementary School }\end{array}$ & 4 & $17.40 \%$ & 10 & $41.70 \%$ & $p=0.398$ \\
\hline & $\begin{array}{l}\text { Completed Elementary } \\
\text { School }\end{array}$ & 4 & $17.40 \%$ & 2 & $8.30 \%$ & \\
\hline & Completed high school & 2 & $8.70 \%$ & 1 & $4.20 \%$ & \\
\hline
\end{tabular}

Note: ACE-R: Addenbrookes Cognitive Examination Revised; DXA: Dual energy X-ray Absorptiometry; GDS: Geriatric Depression Screening scale; M: Mean RAVLT: Rey Auditory-Verbal Learning Test; SD: Standard Deviation; STROOP: Stroop Test; $\mathrm{VO}_{2}$ : Maximum Oxygen consumption; WHOQOL OLD: Quality of Life Instrument for the Elderly. 
Table 1

Characterization of the sample of elderly women participating in the MEMO cognitive training groups $(n=21)$ and the Stimullus cognitive stimulation group $(n=18)$

\begin{tabular}{|c|c|c|c|c|c|c|}
\hline \multirow{2}{*}{ Variables } & \multirow{2}{*}{ Levels } & \multicolumn{2}{|r|}{ Stimullus } & \multicolumn{2}{|r|}{ MEMO } & \multirow{2}{*}{$p$-value } \\
\hline & & $n$ & $\%-M(S D)$ & $n$ & $\%-M(S D)$ & \\
\hline & $\begin{array}{l}\text { Did not complete high } \\
\text { school }\end{array}$ & 9 & $39.10 \%$ & 5 & $20.80 \%$ & \\
\hline & $\begin{array}{l}\text { Did not complete higher } \\
\text { education }\end{array}$ & 0 & $0.00 \%$ & 1 & $4.20 \%$ & \\
\hline & Graduated & 4 & $17.40 \%$ & 5 & $20.80 \%$ & \\
\hline \multirow[t]{6}{*}{ Social class } & $\mathrm{A} 2$ & 3 & $13.00 \%$ & 4 & $16.70 \%$ & $p=0.803$ \\
\hline & B1 & 8 & $34.80 \%$ & 3 & $12.50 \%$ & \\
\hline & B2 & 3 & $13.00 \%$ & 7 & $29.20 \%$ & \\
\hline & C & 2 & $8.70 \%$ & 6 & $25.00 \%$ & \\
\hline & $\mathrm{D}$ & 6 & $26.10 \%$ & 2 & $8.30 \%$ & \\
\hline & $\mathrm{E}$ & 1 & $4.30 \%$ & 2 & $8.30 \%$ & \\
\hline \multirow[t]{2}{*}{ Stroop Delta } & Decreased & 6 & $33.30 \%$ & 8 & $38.10 \%$ & $p=0.760$ \\
\hline & Increased & 12 & $66.70 \%$ & 13 & $61.90 \%$ & \\
\hline \multirow[t]{2}{*}{ RAVLT Delta } & Decreased & 4 & $22.20 \%$ & 8 & $38.10 \%$ & $p=0.291$ \\
\hline & Increased & 14 & $77.80 \%$ & 13 & $61.90 \%$ & \\
\hline \multirow[t]{2}{*}{ ACE-R Total Delta } & Decreased & 9 & $50.00 \%$ & 5 & $23.80 \%$ & $p=0.134$ \\
\hline & Increased & 9 & $50.00 \%$ & 16 & $76.20 \%$ & \\
\hline STROOP 3 & & & $40.39(+12.87)$ & & $39.25(+12.64)$ & $p=0.761$ \\
\hline ACE-R TOTAL (1) & & & $77.22(+14.65)$ & & $77.67(+13.75)$ & $p=0.914$ \\
\hline GDS & & & $4.26(+2.77)$ & & $4.04(+3.07)$ & $p=0.798$ \\
\hline WHOQOL OLD & & & $78.52(+10.01)$ & & $76.08(+9.35)$ & $p=0.393$ \\
\hline Handgrip strength $(\mathrm{kg} / \mathrm{f})$ & & & $44.19(+12.50)$ & & $50.51(+11.58)$ & $p=0.090$ \\
\hline DXA (Fat \%) & & & $39.73(+8.35)$ & & $40.12(+6.17)$ & $p=0.871$ \\
\hline $\mathrm{VO}_{2}$ & & & $18.43(+4.50)$ & & $19.24(+4.21)$ & $p=0.394$ \\
\hline Lean mass & & & $40094.78(+4675.29)$ & & $41510.39(+5850.50)$ & $p=0.544$ \\
\hline
\end{tabular}

Note: ACE-R: Addenbrookes Cognitive Examination Revised; DXA: Dual energy X-ray Absorptiometry; GDS: Geriatric Depression Screening scale; $M$ : Mean, RAVLT: Rey Auditory-Verbal Learning Test; SD: Standard Deviation; STROOP: Stroop Test; $\mathrm{VO}_{2}$ : Maximum Oxygen consumption; WHOQOL OLD: Quality of Life Instrument for the Elderly.

Table 2

General effects of cognitive interventions in the sample of elderly women

\begin{tabular}{|c|c|c|c|c|}
\hline Variables & $M$ & $S D$ & Standard Mean Error & $p$ value \\
\hline STROOP 3 - Time & 37.9500 & 11.60100 & 1.85800 & $p=0.835$ \\
\hline STROOP 3 (2) - Time & 38.4600 & 16.15700 & 2.58700 & \\
\hline Learning curve - A1-A5 & 39.1300 & 9.64700 & 1.54500 & $p<0.001$ \\
\hline Learning curve - A1-A5 (2) & 44.0500 & 10.54800 & 1.68900 & \\
\hline ACE-R - TOTAL (1) & 78.4900 & 13.44200 & 2.15200 & $p=0.167$ \\
\hline ACE-R - TOTAL (2) & 80.1300 & 13.51400 & 2.16400 & \\
\hline GDS - TOTAL (1) & 4.2300 & 2.96000 & 0.47400 & $p=0.095$ \\
\hline GDS - TOTAL (2) & 3.4600 & 3.04200 & 0.48700 & \\
\hline OQL - TOTAL (1) & 77.8500 & 10.19700 & 1.59200 & $p=0.898$ \\
\hline OQL - TOTAL (2) & 78.2000 & 16.54000 & 2.58300 & \\
\hline $\mathrm{HSDH}$ & 48.5214 & 12.15153 & 1.94580 & $p=0.584$ \\
\hline HSNDN & 49.0342 & 11.46538 & 1.83593 & \\
\hline Fat \% (DXA) (1) & 39.7400 & 7.33036 & 1.23906 & $p<0.001$ \\
\hline Fat \% (DXA) (2) & 44.7000 & 9.52767 & 1.61047 & \\
\hline $\mathrm{VO}_{2} \mathrm{ml} / \mathrm{kg} \cdot \mathrm{min}$ ASSESSED (1) & 20.1139 & 3.70897 & 0.66615 & $p=0.394$ \\
\hline $\mathrm{VO}_{2} \mathrm{ml} / \mathrm{kg} \cdot \mathrm{min}$ ASSESSED (2) & 20.5429 & 4.57797 & 0.82223 & \\
\hline Lean mass (DXA) $(g)(1)$ & 40831.5714 & 5723.83508 & 967.50471 & $p<0.001$ \\
\hline Lean mass (DXA) $(\mathrm{g})(2)$ & 37401.1143 & 5371.83104 & 908.00517 & \\
\hline
\end{tabular}

Note: $p$-value obtained using a paired t-test. ACE-R: Addenbrookes Cognitive Examination Revised; DXA: Dual energy X-ray Absorptiometry; GDS: Geriatric Depression Screening Scale; HSDH: Handgrip Strength - Dominant Hand; HSNDN: Handgrip Strength - Non-Dominant Hand; M: Mean; OQL: Overall Quality of Life; SD: Standard Deviation; STROOP: Teste Stroop; $\mathrm{VO}_{2}$ : Maximum Oxygen consumption. 
Table 3

Pre- and post-intervention of older women participating in the MEMO cognitive training program groups $(n=21)$ and the Stimullus cognitive stimulation group $(n=18)$

\begin{tabular}{|c|c|c|c|c|c|c|}
\hline \multirow{2}{*}{ Cognitive Intervention } & \multicolumn{2}{|c|}{ Pre-intervention } & \multicolumn{2}{|c|}{ Post-intervention } & \multirow{2}{*}{ Time factor } & \multirow{2}{*}{ Time $x$ Group } \\
\hline & $M$ & $(S D)$ & $M$ & $(S D)$ & & \\
\hline & \multicolumn{4}{|c|}{ GDS } & & \\
\hline MEMO & 4.05 & $( \pm 3.04)$ & 2.67 & $( \pm 2.85)$ & $\mathrm{F}=2.65 p=0.11$ & $\mathrm{~F}=2.23 p=0.140$ \\
\hline \multirow[t]{2}{*}{ Stimullus } & 4.44 & $( \pm 2.93)$ & 4.39 & $( \pm 3.07)$ & & \\
\hline & \multicolumn{4}{|c|}{ WHOQOL OLD Total } & & \\
\hline MEMO & 76.48 & $( \pm 9.91)$ & 81.29 & $( \pm 10.18)$ & $\mathrm{F}=0.008 p=0.93$ & $\mathrm{~F}=3.14 p=0.084$ \\
\hline \multirow[t]{2}{*}{ Stimullus } & 79.30 & $( \pm 10.53)$ & 74.95 & $( \pm 21.09)$ & & \\
\hline & \multicolumn{4}{|c|}{ Handgrip strength } & & \\
\hline MEMO & 51.47 & $( \pm 11.26)$ & 51.82 & $( \pm 11.09)$ & $\mathrm{F}=0.31 p=0.58$ & $\mathrm{~F}=0.035 p=0.850$ \\
\hline \multirow[t]{2}{*}{ Stimullus } & 45.07 & $( \pm 12.54)$ & 45.77 & $( \pm 11.32)$ & & \\
\hline & \multicolumn{4}{|c|}{ Fat \% (DXA) } & & \\
\hline MEMO & 40.08 & $( \pm 6.37)$ & 45.05 & $( \pm 9.43)$ & $F=22.98 p<0.001$ & $\mathrm{~F}=0.00 p=0.980$ \\
\hline \multirow[t]{2}{*}{ Stimullus } & 39.22 & $( \pm 8.80)$ & 44.16 & $( \pm 9.99)$ & & \\
\hline & \multicolumn{4}{|c|}{$\mathrm{VO}_{2}$} & & \\
\hline MEMO & 20.77 & $(+4.18)$ & 22.23 & $(+5.86)$ & $F=2.75 p=0.10$ & $\mathrm{~F}=2.09 p=0.150$ \\
\hline \multirow[t]{2}{*}{ Stimullus } & 20.53 & $(+3.72)$ & 20.62 & $(+4.22)$ & & \\
\hline & \multicolumn{4}{|c|}{ Lean mass (DXA) } & & \\
\hline MEMO & 44337 & $(+8361)$ & 40969 & $(+9292)$ & $F=18.39 p<0.001$ & $\mathrm{~F}=0.51 p=0.820$ \\
\hline Stimullus & 41553.25 & $(+7096)$ & 37808.81 & $(+6708)$ & & \\
\hline
\end{tabular}

Note: 2x2 ANOVA, p > 0,05. DXA: Dual energy X-ray Absorptiometry; GDS: Geriatric Depression Screening Scale; M: Mean; SD: Standard Deviation; VO2: Maximum Oxygen consumption; WHOQOL OLD Quality of Life Instrument for the Elderly.

\section{Discussion}

In the findings of the present study, the investigated elderly women tended to reduce depressive symptoms, increase their fat mass and decrease their lean mass levels, suggesting that training does not favor improvements in the investigated physical fitness variables, which demonstrates that regardless of the type of training, the physical fitness variables worsened after the test. The 2x2 ANOVA test analyzes also showed a trend towards higher scores in the MEMO Group when compared to those in the Stimullus Group, according to the WHOQOL OLD Scale.

Other studies, such as the one by Ross et al. (2018), when analyzing two- and five-year longitudinal data in elderly Americans participating in the ACTIVE Study, found that a greater participation in inductive reasoning training was associated with greater handgrip strength levels; and according to the same authors, different types of training did not increase physical performance, but decreased decline over time (Ross et al., 2018). Thus, there is a relationship between the cognitive and physical variables, but the directionality and the relationship between them needs to be better elucidated.

For example, Li et al. (2010) found that computerized cognitive training of visual discrimination had improved standing balance, however multiple cognitive training observed changes in balance and gait speed in elderly individuals (Makowski-Woidan, \& Hughes, 2014; Smith-Ray et al., 2013; Verghese, Mahoney, Ambrose, Wang, \& Holtzer, 2010). Therefore, the studies conducted so far indicate the relationship between cognitive training and physical fitness seems to be directed to variables associated with standing balance and gait speed. Findings investigating these variables in mnemonic training are scarce and to date there are no data regarding the Brazilian population. It is possible that if the investigated physical fitness variables considered standing balance and gait speed, there would be a relationship between training and improvement of mnemonic performance, and this hypothesis may be tested in subsequent studies. 
Although a trend towards higher WHOQOL OLD scores was observed in the MEMO Group when compared to the Stimullus group, the absence of changes in the quality of life indicators can be explained by differences in the design of the ACTIVE studies, including cultural and socioeconomic differences, such as lower educational levels; and methodological differences, such as the short period of time to investigate the relationship between cognitive interventions and quality of life. In a Brazilian study, although the study by Irigaray et al. (2014) showed an increase in quality of life, there are important methodological differences with the present study: the authors compared performance differences between the Experimental Group and the Control Group; where the experimental group received 12 cognitive training sessions, consisting of four attention training sessions, four memory training sessions and four executive function training sessions. The control group, on the other hand, did not receive any intervention. In the present study, the researchers compared a mnemonic intervention versus a global cognitive stimulation intervention, which may have contributed to not altering the quality of life indicators in the comparison between groups. In addition, six training sessions were offered, unlike the study by Irigaray et al. (2014) who offered twelve, focusing on different cognitive skills.

In this regard, it is discussed in the literature on cognitive interventions the best model to compose the control group, since passive control (without intervention) would capture only the test-retest effect of evaluations, whereas active control (with educational or another type of cognitive intervention) can have benefits related to socialization and acquisition of new knowledge. The fact is that the present study was characterized by an exploratory research, whose focus was the comparison between cognitive stimulation and cognitive training.

Findings about the reduction of depressive symptoms in elderly participants of cognitive training programs have been documented in Brazilian studies by Salmazo-Silva and Yassuda (2009); Brum et al. (2009); Casemiro et al. (2016); Tavares, Schmidt, and Witter (2015); and in review studies, such as the one by Reijnders et al. (2013). It is possible that cognitive training maximizes social interaction and group living, as well as bringing changes in the subjective perception of memory, reducing depressive symptoms. It is important to highlight that, in this study, both groups (MEMO and Stimullus) attended group interventions and already had low levels of depressive symptoms at the beginning of the intervention. Thus, other studies may test what is the most favorable training for reducing depressive symptoms in healthy elderly individuals, in order to test if the strategies taught influence depressive symptoms, as in the study by Salmazo-Silva and Yassuda (2009), in which the group of illiterate elderly individuals who trained mental images had fewer depressive symptoms than the group that trained categorization.

In summary, the findings of the present study indicate that the effects of MEMO and Stimullus training were selective for episodic memory and were not associated with improvements in the mood, quality of life and physical fitness variables. Beleville et al. (2018), when testing the impact of MEMO training in elderly individuals with mild cognitive decline, also did not observe any time and group factor influences on depressive symptoms and well-being measures when compared to the active control group that performed psychosocial interventions. Thus, Beleville et al. (2018) discusses the need to verify the impact of training in elderly individuals with high levels of depressive symptoms and anxiety.

However, it is possible that the observed results are related to the limitations of the present study, such as: the analysis of a sample composed only of women; not having controlled the analyzes by clinical measures that could affect the level of physical performance; the reduced sample size to estimate effect sizes of the interventions on the investigated variables; not including a control group (passive or active); and the low score of the different fitness values at baseline. Despite these limitations, the findings of this study may help in the discussion about the directionality of cognitive interventions on the subjective and physical performance variables, in order to investigate the outcomes and factors associated with these interventions in Brazilian elderly individuals. This is especially important in current studies that measure combined (cognitive and physical) interventions on cognitive aging, in order to maximize the individuals' well-being and quality of life. 


\section{Contributors}

I. P. F. S. CHARIGLIONE participated in the general conception, writing, analysis of psychological and cognitive data and general review of this article. H. S. SILVA participated in the writing, cognitive data analysis and general review. G. F. MELO undertook physical data analysis and general review. K. H. C. V. SILVA did the writing, physical data analysis and general review. M. L. C. OLIVEIRA was responsible for the writing, social data analysis and general review of this article.

\section{References}

Almeida, O. P., \& Almeida, S. A. (1999). Confiabilidade da versão brasileira da Escala de Depressão em Geriatria (GDS) versão reduzida. Arquivos de Neuro-Psiquiatria, 57(2b), 421-426. http://dx.doi.org/10.1590/S0004-282X1999000300013

Araújo, D. S. M. S, \& Araújo, C. G. S. (2000). Aptidão física, saúde e qualidade de vida relacionada à saúde em adultos. Revista Brasileira de Medicina do Esporte, 6(5), 194-203. http://dx.doi.org/10.1590/\$1517-86922000000500005

Bahar-Fuchs, A., Clare, L., \& Woods, B. (2013). Cognitive training and cognitive rehabilitation for persons with mild to moderate dementia of the Alzheimer's or vascular type: a review. Alzheimer's Research \& Therapy, 5(35), 1-14. http:// dx.doi.org/10.1186/alzrt189

Belleville, S., Hudon, C., Bier, N., Brodeur, C., Gilbert, B., Grenier, S., ... Gauthier, S. (2018). MEMO+: efficacy, durability and effect of cognitive training and psychosocial intervention in individuals with mild cognitive impairment. Journal of American Geriatric Society, 66(4), 655-663. http://dx.doi.org/10.1111/jgs.15192

Brucki, S. M. D., Nitrini, R., Caramelli, P., Bertolucci, P. H. F., \& Okamoto, I. H. (2003). Sugestões para o uso do Miniexame do Estado Mental no Brasil. Arquivos de Neuropsiquiatria, 61(3B), 777-781. http://dx.doi.org/10.1590/S0004-282X2003000500014

Brum, P. S., Forlenza, O. V., \& Yassuda, M. S. (2009) Cognitive training in older adults with Mild Cognitive Impairment: impact on cognitive. Dementia \& Neuropsychologia, 3(2), 124-131. http://dx. doi.org/10.1590/S1980-57642009DN30200010

Cabeza, R., Albert, M., Belleville, S., Craik, F. I. M., Duarte, A., Grady, C. L., ... Rajah, M. N. (2018). Maintenance, reserve and compensation: the cognitive neuroscience of healthy ageing. Nature Reviews Neuroscience, 19, 701-710. Retrieved from https:// www.nature.com/articles/s41583-018-0068-2

Carvalho, V. A., \& Caramelli, P. (2007). Brazilian adaptation of the Addenbrooke's Cognitive Examination-Revised (ACE-R). Dementia \& Neuropsychologia, 1(2), 212-216. http://dx.doi.org/10.1590/s1980-57642008dn10200015

Casemiro, F. G., Rodrigues, I. A., Dias, J. C., Alves, L. C. S., Inouye, K., \& Gratão, A. C. M. (2016). Impacto da estimulação cognitiva sobre depressão, ansiedade, cognição e capacidade funcional em adultos e idosos de uma universidade aberta da terceira idade. Revista Brasileira de Geriatria e Gerontologia, 19(4), 683-694. http://dx.doi.org/10.1590/180998232016019.150214

Chariglione, I. P. F., \& Janczura, G. A. (2013). Contribuições de um treino cognitivo para a memória de idosos institucionalizados. Psico-USF, Bragança Paulista, 18(1), 13-22. Recuperado de http://www.scielo.br/pdf/pusf/v18n1/v18n1a03.pdf

Chariglione, I. P. F. S., Salmazo-Silva, H., Silva, A. A., Sacramento, A. M., \& Melo, G. F. (2018a). Cognitive performance and physical fitness in the health of Brazilian elderly women. Revista Brasileira de Psicologia do Esporte, 8(2), 1-16. http://dx.doi. org/10.31501/rbpe.v8i2.9875

Chariglione, I. P. F. S., Janczura, G. A., \& Belleville, S. (2018b). Cognitive interventions to improve memory in healthy older adults: the use of Canadian (MEMO) and Brazilian (Stimullus) approaches. Estudos de Psicologia (Natal), 23(1), 2-13. http://dx. doi. org/10.22491/1678-4669.20180 002

Fechine, B. R. A., \& Trompieri, N. (2012). O processo de envelhecimento: as principais alterações que acontecem com o idoso com o passar dos anos. InterSciencePlace, 1(20), 106-132. http://dx. doi.org/10.6020/1679-9844/2007

Fernández-Prado S., Conlon, S., Mayán-Santos, J. M., \& Gandoy-Crego, M. (2012). The influence of a cognitive stimulation program on the quality of life perception among the elderly. Archives of Gerontology and Geriatrics, 54(1), 181-184. http:// dx.doi.org/10.1016/J.archger.2011.03.003

Fleck, M. P. A., Chachamovich, E., \& Trentini, C. M. (2003). Projeto WHOQOL-OLD: método e resultados de grupos focais no Brasil. Revista de Saúde Pública, 37(6), 793-799. http://dx.doi.org/10.1590/S0034-89102003000600016

Gagnon, L. G., \& Belleville, S. (2012) Training of attentional control in mild cognitive impairment with executive deficits: results from a double-blind randomised controlled study. Neuropsychological Rehabilitation, 22(6), 809-835. http://dx.doi.org/10.10 80/09602011.2012.691044 
Gilbert, B., Fontaine, F. S., \& Belleville, S. (2011). Programme MEMO: méthode d'entraînement pour une mémoire optimal. Guide à l'intention des animateurs. Montréal: Institut Universitaire de Gériatrie de Montréal.

Huntley, J. D., Gould, R. L, Liu, K., Smith, M. R., \& Howardet, J. (2015). Do cognitive interventions improve general cognition in dementia? a meta-analysis and meta-regression. BMJ Open; 5, e005247. http://dx.doi.org/10.1136/ bmjopen-2014-005247

Irigaray, T. Q., Schneider, R. H., \& Gomes, I. (2014). Effects of a cognitive training on the quality of life and well-being of healthy elders. Psicologia: Reflexão e Crítica, 24(4), 810-818. http://dx.doi.org/10.1590/S0102-79722011000400022

Kennedy, G., Hardman, R. J., Macpherson, H., Scholey, A. B., \& Pipingas, A. (2016). How does exercise reduce the rate of age-associated cognitive decline? a review of potential mechanisms. Journal of Alzheimer's Disease, 55(1), 1-18. http://dx.doi.org/10.3233/JAD-160665

Lawton, M. P. (1991). A multidimensional view of quality of life in frail elderly. In J. E. Brien, J. E. Lubben, J. C. Rowe, \& D. E. Deutchmann (Eds.), The concept and measurement of quality of life in the frail elderly (pp.3-27). San Diego: Academic Press.

Li, K. Z., Roudaia, E., Lussier, M., Bherer, L., Leroux, A., \& McKinley, P. A. (2010). Benefits of cognitive dual-task training on balance performance in healthy older adults. Journal of Gerontology: Series A, 65(12), 1344-1352. http://dx.doi. org/10.1093/gerona/glq151

Neri, A. L., Yassuda, M. S., Araújo, L. F., Eulálio, M. C., Cabral, B. E., Siqueira, M. E. C., ... Moura, J. G. A. (2013). Metodologia e perfil sociodemográfico, cognitivo e de fragilidade de idosos comunitários de sete cidades brasileiras: estudo FIBRA. Cadernos de Saúde Pública, 29(4), 778-792. http://dx.doi.org/10.1590/S0102-311X2013000400015

Neri, A. L., Borim, F. S. A., Fontes, A. P., Rabello, D. F., Cachioni, M., Batistoni, S. S. T., ... Lima-Costa, M. F. (2018). Fatores associados à qualidade de vida percebida em adultos mais velhos: ELSI-Brasil. Revista de Saúde Pública, 52(2), 1-10. http://dx.doi.org/10.11606/s1518-8787.2018052000613

Pesce, M., Tatangelo, R., La-Fratta, I., Rizzuto, A., Campagna, G., Turli, C., ... Grilli, A. (2017). Memory training program decreases the circulating level of cortisol and pro-inflammatory cytokines in healthy olders. Frontiers in Molecular Neuroscience, 10(233). http://dx.doi.org/10.3389/fnmol.2017.00233

Reijnders, J., Van-Heugten, C., \& Van-Boxtel, M. (2013). Cognitive intervention in healthy older adults and people with mild cognitive impairment: a systematic review. Ageing Research Reviews, 12(1), 263-275. http://dx.doi.org/10.1016/j. arr.2012.07.003

Ross, L. A., Sprague, B. N., Phillips, C. B., O'Connor, M. L., \& Dodson, J. E. (2018). The impact of three cognitive training interventions on older adult's physical functioning across 5 years. Journal of Aging and Health, 30(3), 475-498. http://dx.doi. org/10.1177/0898264316682916

Salgado, J. V., Malloy-Diniz, L. F., Abrantes, S. S. C., Moreira, L., Schlottfeldt, C. G., Guimarães, W., ... Fuentes, D. (2011). Applicability of the Rey Auditory-Verbal Learning Test to an adult sample in Brazil. Revista Brasileira de Psiquiatria, 33(3), 234-237. http://dx.doi.org/10.1590/S1516-44462011005000007

Salmazo-Silva, H., \& Yassuda, M. S. (2009). Memory training for older adults with low education: mental images versus categorization. Educational Gerontology, 35(10), 890-905. http://dx.doi.org/10.1080/03601270902782487

Shiratori, A. P., Rosa, R. I., Borges Júnior, N. G., Domenech, S. C., \& Silva-Gevaerd, M. (2014). Protocolos de avaliação da força de preensão manual em indivíduos com artrite reumatoide: uma revisão sistemática. Revista Brasileira de Reumatologia, 54(2), 140-147. http://dx.doi.org/10.1016/j.rbr.2014.03.009

Silva, V. R. R., Souza, G. R., \& Crepaldi-Alves, S. C. (2015). Benefícios do exercício físico sobre as alterações fisiológicas, aspectos sociais, cognitivos e emocionais no envelhecimento. Revista Centro de Pesquisas Avançadas em Qualidade de Vida, 7(3), 1-12. Recuperado de http://www.cpaqv.org/revista/CPAQV/ojs-2.3.7/index.php?journal =CPAQV\&page $=$ article\&op=view $\&$ path $\% 5 B \% 5 \mathrm{D}=87$

Smith-Ray, R. L., Hughes, S. L., Prohaska, T. R., Little, D. M., Jurivich, D. A., \& Hedeker, D. (2013). Impact of cognitive training on balance and gait in older adults. Journal of Gerontology: Series B, 70(3), 357-366. http://dx.doi.org/10.1093/ geronb/gbt097

Smith-Ray, R. L., Makowski-Woidan, B., \& Hughes, S. L. (2014). A randomized trial to measure the impact of a communitybased cognitive training intervention on balance and gait in cognitively intact black older adults. Health Education \& Behavior, 41(1), 62S-69S. http://dx.doi.org/10.1177/1090198114537068

Stroop, J. R. (1935). Studies of interference in serial verbal reactions. Journal of Experimental Psychology, 18(6), 643-662. http://dx.doi.org/10.1037/h0054651

Tabachnick, B. G., \& Fidell, L. S. (2012). Using Multivariate Statistics (6th ed.). Boston: Person Education. 
Tavares, P., Schmidt, J., \& Witter, C. (2015). Efeitos de um programa de intervenção no desempenho cognitivo e sintomatologia depressiva em idosos institucionalizados. Revista Kairós: Gerontologia, 18(2), 103-123. Recuperado de http://ken.pucsp.br/kairos/article/ view/26316

Verghese, J., Mahoney, J., Ambrose, A. F., Wang, C., \& Holtzer, R. (2010). Effect of cognitive remediation on gait in sedentary seniors. Journal of Gerontology: Series A, 65(12), 1338-1343. http://dx.doi.org/10.1093/gerona/glq127

Viscogliosi, C., Desrosiers, J., \& Belleville, S. (2019). Optimizing participation of older adults with cognitive deficits post-stroke: types of help and caregiver burden. Canadian Journal on Aging/La Revue Canadienne Du Vieillissement, 38(2), 1-14. http://dx.doi.org/10.101 7/S0714980818000521

World Health Organization Quality of Life Group. (1998). The World Health Organization quality of life assessment (WHOQOL): development and general psychometric properties. Social Science and Medicine, 46(12), 1569-1585. Retrieved from https://www.ncbi.nlm. nih.gov/pubmed /96 72396

Wolinsky, F. D., Unverzagt, F. W., Smith, D. M., Jones, R., Wright, E., \& Tennstedt, S. L. (2006a). The effects of the ACTIVE Cognitive training trial on clinically relevant declines in health-related quality of live. Journal of Gerontology: Series $B$, 61(5), 281-287. Retrieved from https://www.ncbi.nlm.nih.gov/pubmed/16960242

Wolinsky, F. D., Unverzagt, F. W., Smith, D. M., Jones, R., Stoddard, A., \& Tennstedt, S. L. (2006b). The ACTIVE cognitive training trial and health-related quality of life: protection that lasts for 5 years. Journal of Gerontology: Series $A$, 61(12), 1324-1329. http://dx.doi. org/10.1093/gerona/61.12.1324

Yesavage, J., Brink, T., Rose, T., Lun, O., Huang, V., Adey, N., \& Leirer, V. (1983). Development and validation of a geriatric depression scale: a preliminary report. Journal of Psychiatric Research, 17(1), 37-49. Retrieved from https://pdfs. semanticscholar.org /5ab1/91352d3f0b530936ca9acae91245896c8cef.pdf

Received: April 5, 2019

Final version: October 17, 2019

Approved: November 21, 2019 